\title{
KAJIAN KRIMINOLOGI TERHADAP UPAYA PENANGANAN KASUS KEKERASAN DALAM RUMAH TANGGA (KDRT) DI INDONESIA
}

\author{
Prisilla Viviane Merung \\ email: prisillaviviane@gmail.com
}

\begin{abstract}
Domestic violence had been and is still underreported. Inhibiting factor is the widely held perception that outside intervention in cases of domestic violence is unwelcome and asking outside help will bring shame to the family. It is and should be treated by family members among themselves. To make matter worse, there is the general tendency to shift the blame to the victim. This article discusses domestic violence, especially those directed against women, from the legal (normative) as well as criminological perspective. It is telling that after its recognition as a special crime by virtue of the Penal Code (in general terms) and by Law no. 23 of 2004 re. abolition of domestic violence, the public perception shifted for the better. Consequently, more and more victims of domestic violence, with the support of their families, report their case to the police.
\end{abstract}

Keywords:

Criminology, Violence against women, Domestic violence.

\begin{abstract}
Abstrak
Kekerasan dalam rumah tangga umumnya sulit untuk terungkap dan jarang dilaporkan dan diperiksa sebagai tindak pidana. Selain dianggap urusan internal dan pelaporan membuat malu keluarga, masyarakat cenderung pula menyalahkan korban. Tulisan ini akan menyoroti fenomena kekerasan dalam rumah tangga, khususnya terhadap perempuan, baik dari sudut pandang pengaturannya di dalam hukum maupun dari perspektif kriminologis. Dapat dicermati bahwa sejak pengaturannya sebagai kejahatan baik secara umum di dalam KUHPidana dan kemudian secara khusus di dalam Undang-Undang No. 23 tahun 2004 tentang Penghapusan Kekerasan Dalam Rumah Tangga persepsi umum masyarakat tentang KDRT mengalami perubahan.. Hal ini terbukti dari meningkatnya laporan tentang laporan KDRT.
\end{abstract}

Kata Kunci: Kriminologi, Kekerasan terhadap perempuan, KDRT.

\section{Pengantar}

Keutuhan dan kerukunan rumah tangga yang bahagia, aman, dan damai merupakan dambaan setiap orang dalam rumah tangga. Untuk mewujudkan keutuhan dan kerukunan tersebut sangat tergantung pada setiap orang dalam lingkup rumah tangga, terutama kadar kualitas perilaku dan pengendalian diri setiap orang dalam lingkup rumah tangga tersebut. Keutuhan dan kerukunan 
keluarga dapat terganggu jika kualitas dan pengendalian diri tidak dapat dikontrol, yang pada akhirnya terjadi kekerasan dalam rumah tangga sehingga timbul ketidakamanan atau ketidakadilan terhadap orang yang berada dalam lingkup rumah tangga tersebut. Untuk menegakkan hukum terhadap pelaku kekerasan dalam rumah tangga, negara dan masyarakat harus memahami dengan benar faktor-faktor yang menyebabkan terjadinya tindak kekerasan dalam rumah tangga, sehingga memudahkan melakukan pencegahan, perlindungan dan penindakan pelaku sesuai dengan falsafah Pancasila dan Undang-Undang Dasar Negara Republik Indonesia Tahun 1945. Pada dasarnya pernikahan yaitu membentuk suatu keluarga yang bahagia dan kekal serta membangun, membina dan memelihara hubungan kekerabatan yang rukun dan damai di samping untuk memperoleh keturunan. Sesuai dengan Pasal 1 ayat (1) Undang-undang Nomor 1 Tahun 1974 Tentang Perkawinan, dinyatakan bahwa:

"Perkawinan merupakan ikatan lahir batin antara seorang pria dengan seorang wanita sebagai suami isteri dengan tujuan membentuk keluarga (rumah tangga) yang bahagia dan kekal berdasarkan Ketuhanan Yang Maha Esa."

Kasus-kasus kekerasan dalam rumah tangga, khususnya terhadap isteri yang terjadi pada saat ini mengalami peningkatan baik dari segi kuantitasnya maupun dari segi kualitasnya. Hal ini tentunya mendapat perhatian dari semua pihak untuk mengetahui bentuk-bentuk kekerasan, faktor-faktor penyebabnya dan bagaimana perlindungan hukum bagi isteri yang menjadi korban kekerasan suami. Kekerasan dalam rumah tangga yang dapat kita lihat melalui kekerasan terhadap isteri bervariasi, seperti kekerasan fisik, psikis, seksual dan kekerasan berupa penelantaran, hal ini diancam dengan ketentuan pidana yang terdapat pada Undang-undang Nomor 23 Tahun 2004 Tentang penghapusan kekerasan dalam rumah tangga. Penegakan hukum terhadap pelaku kekerasan dalam rumah tangga terhadap istri dapat menggunakan aturan-aturan hukum baik dalam Kitab Undang-undang Hukum Pidana (KUHP), Undang-undang Nomor 1 Tahun 1974 Tentang Perkawinan maupun Undang-undang Nomor 23 Tahun 2004 Tentang 
Penghapusan Kekerasan Terhadap Rumah tangga. Dalam Penjelasan Umum Undang-undang Nomor 1 Tahun 1974 tujuan perkawinan yaitu membentuk keluarga yang bahagia dan kekal. Untuk itu suami isteri perlu saling membantu dan melengkapi, agar masing-masing dapat mengembangkan kepribadiannya membantu dan mencapai kesejahteraan spritual dan material. Kemudian dalam pasal 33 Undang-Undang Nomor 1 Tahun 1974 Tentang Perkawinan dapat kita lihat dengan adanya ketentuan yang menentukan hak dan kewajiban suami isteri, yaitu wajib saling mencintai, hormat menghormati, setia dan memberi bantuan lahir batin yang satu kepada yang lain.

Kedua pasal di atas menggambarkan adanya larangan kekerasan dalam rumah tangga termasuk kekerasan oleh suami terhadap isteri. Apalagi menurut pandangan bangsa Indonesia bahwa Lembaga Perkawinan adalah lembaga yang sakral. Namun kenyataan membuktikan, bahwa telah terjadi kekerasan yang di alami oleh perempuan, khususnya isteri, yang dilakukan suami terhadap isteri. Berbagai bentuk kekerasan fisik kepada isteri tidak hanya bersifat fisik seperti melempar sesuatu, memukul, menampar, sampai membunuh. Namun juga bersifat non fisik seperti menghina, berbicara kasar dan ancaman. Kekerasan seperti ini adalah termasuk dalam bentuk kekerasan psikologi/kejiwaan. Kasuskasus seperti di atas masih banyak yang tidak dilaporkan dengan alasan bahwa, hal ini merupakan urusan intern keluarga.

Masalah utama yang perlu mendapat perhatian adalah perlindungan hukum bagi perempuan khususnya isteri yang menjadi korban kekerasan suami. Walaupun dalam Kitab Undang-Undang Hukum Pidana ada beberapa pasal yang mampu menjerat perlakuan kekerasan ini, namun tindak kekerasan suami terhadap isteri masih sering terjadi. Upaya untuk menemukan indikasi-indikasi yang berkaitan dengan kekerasan terhadap isteri oleh suami perlu mendapat perhatian serius. Dengan ditemukan indikasi-indikasi tersebut, dapat diketahui faktor-faktor yang menyebabkan terjadinya kekerasan terhadap isteri dan dapat dilakukan pencegahan dengan penanganan serta penanggulangannya. 
Michel Victory dalam Teori Siklus Kekerasan (Cycle of Violence) menerangkan dan membagi 5 fase kekerasan dalam rumah tangga yaitu: 1

1. Fase Permulaan (Build - Up Phase)

Dalam fase ini mulai ada ketegangan di antara pasangan. Jika suami - istri tidak memiliki kemampuan mengatasi maka ketegangan akan memuncak.

2. Fase Kekerasan (Stand - Over Phase)

Laki-Laki mulai menggunakan kekuatan yang dimiliki (Fisik, psikologi, dan ekonomi) untuk menguasai pasangannya.

3. Fase Penyesalan (Remorse Phase)

Pelaku sering mersasa bersalah atas perbuatannya atau takut terhadap ancaman pidana. Mereka mulai mencoba menolak serius perbuatannya.

4. Fase Penebusan (Pursuit or buy - Back Phase)

Pelaku mencoba menebus perbuatannya dngan hadiah dan janji bahwa dia akan berubah untuk membuat pasangan tidak pergi. Bila gagal, KDRT tetap berlanjut.

5. Fase Bulan Madu (Honeymoon Phase)

Setelah KDRT terjadi kedua pasangan kembali rujuk.

Berdasarkan hasil penelitian, ditemukan kasus Kekerasan dalam Rumah tangga yang dilakukan oleh suami terhadap isteri disebabkan karena faktor ekonomi lemah, suami pengangguran dan mempunyai sifat temperamental. Sehingga KDRT bukan terletak pada apa kriterianya, tetapi lebih pada alasan mengapa perilaku kekerasan itu dapat menerpa sebuah keluarga.

\section{Pembahasan}

Pertama-tama perlu digariskan bahwa kajian ini merupakan kajian Kriminologi. Karena merupakan kajian kriminologi, maka kriminologi akan mendominasi pemaparan selanjutnya. Ini dimaksudkan agar ada batasan yang

\footnotetext{
${ }^{1}$ Miranda Davies, (Ed.) women and violence: Realities and Responses World Wide, 2nd ed, London and new York; zed books Ltd., 1997.
} 
jelas mengenai kajian tersebut. Menurut Romli Atmasasmita², jika kekerasan dikaitkan dengan kejahatan, maka kekerasan sering merupakan pelengkap dari kejahatan itu sendiri, bahkan, ia telah membentuk ciri tersendiri dalam khasanah tentang studi kejahatan. Semakin menggejala dan menyebar luas frekuensi kejahatan yang diikuti dengan kekerasan dalam masyarakat, maka semakin tebal keyakinan masyarakat akan penting dan seriusnya kejahatan semacam ini. ${ }^{3}$

Kriminologi adalah ilmu pengetahuan tentang kejahatan. Secara etimologis kriminologi berasal dari kata crimen berarti kejahatan dan logos yang artinya pengetahuan atau ilmu pengetahuan. Istilah kriminologi pertama kali digunakan oleh P. Topinard, seorang ahli antropologi Perancis. Terjadinya kejahatan dan penyebabnya telah menjadi subyek yang banyak mengundang perdebatan, dengan spekulasi, teoritisasi, penelitian di antara para ahli maupun masyarakat. Banyaknya teori yang berusaha menjelaskan tentang masalah kejahatan walaupun teori-teori tersebut banyak dipengaruhi oleh agama, ekonomi, filsafat dan politik.

Menurut E.H. Sutherland, kriminologi adalah seperangkat pengetahuan yang mempelajari kejahatan sebagai fenomena sosial, termasuk di dalamnya proses pembuatan Undang-Undang, pelanggaran Undang-Undang, dan reaksi terhadap pelanggaran Undang-Undang. Para filosof Yunani kuno seperti Aristoteles dan Plato sudah menjelaskan studi tentang kejahatan ini di jaman mereka, khususnya usaha untuk menjelaskan sebab-sebab kejahatan. Walaupun studi tentang kejahatan (kriminologi) secara ilmiah dianggap baru lahir pada abad 19, yaitu dengan ditandai lahirnya statistik kriminal di Perancis pada tahun 1826 atau dengan diterbitkannya buku L'Uomo Delinguente tahun 1876 oleh Cesare Lombroso. Pemahaman dan analisa kriminologi dapat didayagunakan untuk

\footnotetext{
${ }^{2}$ Romli Atmasasmita, Teori dan Kapita Selekta Krimonologi, Refika Aditama, Bandung, 2007, hlm. 63

3 Id., hlm., 66.
} 
kepentingan tercapainya tujuan-tujuan pembangunan nasional sesuai dengan tuntutan rakyat indonesia. ${ }^{4}$ Menurut Sanford, definisi dari kekerasan adalah:

"All types of illegal behavior, either threatened or actual that result in the damage or destruction of property or in the injury or death of an individual" (semua bentuk perilaku illegal, termasuk yang mengancam atau merugikan secara nyata atau menghancurkan harta benda atau fisik atau menyebabkan kematian)."

Menurut Douglas dan Waksler istilah kekerasan sebenarnya digunakan untuk menggambarkan perilaku, baik yang terbuka (overt) atau tertutup (covert), baik yang bersifat menyerang (offensive) atau yang bertahan (defensive), yang disertai penggunaan kekuatan kepada orang lain. Oleh karena itu secara umum ada empat jenis kekerasan:

1. Kekerasan terbuka, kekerasan yang dilihat, seperti perkelahian;

2. Kekerasan tertutup, kekerasan yang tersembunyi atau tidak dilakukan, seperti mengancam;

3. Kekerasan agresif, kekerasan yang dilakukan tidak untuk perlindungan, tetapi untuk mendapatkan sesuatu, seperti penjabalan; dan

4. Kekerasan defensive, kekerasan yang dilakukan untuk perlindungan diri.

Baik kekerasan agresif maupun defensif bisa bersifat terbuka atau tertutup. Perspektif definisi kekerasan di atas lebih menekankan pada sifat dari sebuah kekerasan. Bagaimana sebuah kekerasan itu disebut terbuka, tertutup, agresif dan ofensif. Kiranya ini akan dapat dihubungkan dengan kekerasan macam apa yang terjadi dalam sebuah rumah tangga.

Menurut Sally E. Merry, ${ }^{\mathbf{5}}$ Kekerasan adalah:

"Suatu tanda dari perjuangan untuk memelihara beberapa fantasi dari identitas dan kekuasaan. Kekerasan muncul, dalam analisa tersebut, sebagai sensitivitas gender dan jenis kelamin". Sangat filosofis pendapat Sally ini, namun dapat ditangkap maknanya bahwa perilaku kekerasan sangat berkorelasi dengan kehausan akan bagaimana mengekspresikan dirinya, bahwa dialah yang memiliki kekuatan

\footnotetext{
${ }^{4}$ http://pipi-megawati.blogspot.com/2011/10/kriminologi.html, Diakses tanggal 15 Januari 2016.

${ }^{5}$ Blog Jurnal Hukum, perlindungan terhadap perempuan melalui undang-undang kekerasan dalam rumah tangga: analisa perbandingan antara Indonesia dan India, Diakses tanggal 28 Januari 2016.
} 
(power) dan karenanya dia pun patut melakukan apa saja termasuk kekerasan baik terhadap isterinya bahkan anak-anaknya."

Konsepsi kekerasan sebagai kejahatan dalam konteks kehidupan berumah tangga, sebagaimana yang dikonsepsikan dalam Undang-Undang Nomor 23 Tahun 2004 tentang Penghapusan Kekerasan Dalam Rumah Tangga selanjutnya disebut UU PKDRT, adalah sebagai berikut:

"Kekerasan dalam Rumah Tangga adalah setiap perbuatan terhadap seseorang terutama perempuan, yang berakibat timbulnya kesengsaraan atau penderitaan secara fisik, seksual, psikologis, dan/atau penelantaran rumah tangga termasuk ancaman untuk melakukan perbuatan, pemaksaan, atau perampasan kemerdekaan secara melawan hukum dalam lingkup rumah tangga". ${ }^{6}$

Bila rumusan Undang-Undang PKDRT dikoneksikan dengan konsepsi kekerasan sebelumnya, maka dapat ditemukan benang merah yang sangat erat antara kejahatan dengan kekerasan. Karenanya kekerasan sebagai bagian dari kejahatan, perlu dinormakan secara positif agar memiliki kepastian hukum yang jelas. Karena salah satu fungsi Undang-Undang adalah memagari masyarakat agar tidak semena-mena terhadap orang lain. ${ }^{7}$

Di samping itu kasus kekerasan dalam rumah tangga dianggap persoalan privat, karena merupakan persoalan pribadi maka masalah-masalah KDRT dianggap sebagai rahasia keluarga. Padahal, justru anggapan ini membuat masalah ini sulit dicarikan jalan pemecahannya. Selama ini KDRT diidentifikasikan dengan delik aduan. Padahal kalau dilihat dari Pasal 351 KUHP (tentang penganiayaan) dan Pasal 356 (tentang Pemberatan, ternyata tidak diisyaratkan adanya aduan). Hanya saja khususnya penegak hukum, jika suatu kejahatan yang berhubungan dengan keluarga, maka dilihat sebagai delik aduan padahal itu adalah kasus kriminal murni yang merupakan delik biasa. Sehingga jika meskipun kemudian korban menarik aduannya, maka hendaknya penegak hukum dapat

\footnotetext{
6 Pasal 1 Undang-Undang No. 23 Tahun 2004 tentang Penghapusan Kekerasan Dalam Rumah Tangga.

7 www.pemantauperadilan.com, Kekerasan Dalam Rumah Tangga, Diakses tanggal 29 Januari 2016.
} 
meneruskannya ke pengadilan. Penelitian ini dimulai dengan meneliti dan mencermati perundang-undangan baik yang terkait dengan faktor-faktor kriminologis dalam data sekunder. ${ }^{8}$

\section{Fenomena KDRT yang terjadi di kalangan masyarakat ditinjau dari aspek Kriminologi}

Secara umum kriminologi bertujuan mempelajari kejahatan dari berbagai aspek, sehingga pemahaman tentang fenomena kejahatan akan bisa diperoleh dengan baik. Dalam sejarah intelektual, terhadap masalah penjelasan secara umum dapat dibedakan dua cara pendekatan yang mendasar yaitu pendekatan spiritistik atau demonologik dan pendekatan naturalistik, kedua-duanya merupakan pendekatan pada masa kuno maupun modern. Dalam proses pembangunan tak jarang ditemui hambatan-hambatan yang terwujud sebagai bentuk-bentuk kejahatan, mulai dari kejahatan individual dan konvensional sampai pada kejahatan-kejahatan inkonvensional.

Kekerasan Dalam Rumah Tangga (KDRT) jika ditinjau dari aspek kriminologis, dapat digambarkan bahwa KDRT terjadi oleh faktor-faktor sebagaimana yang dikaji dari sudut etiologi kriminal. Sehingga berdasarkan pendapat Sutherland fenomena KDRT itu dapat ditemukan sebab-sebabnya sebagai berikut:

a) Ekonomi

Ekonomi sebagai faktor penyebab terjadinya KDRT, berhubungan dengan income (penghasilan) keluarga. Kebutuhan yang besar dengan penghasilan yang kecil memicu terjadinya KDRT. Ketika kebutuhan anggota keluarga tidak dapat diakomodir, maka kekerasan akan mulai menggeliat/merupakan senjata (ultimum remedium) untuk meredam permintaan para anggota keluarga.

\footnotetext{
8 Soerjono Soekanto, Faktor-faktor yang Mempengaruhi Penegakan Hukum, Raja Grafindo Perkasa, Jakarta, Cet. ke13, 2014.
} 
b) Cemburu

Cemburu selalu menghiasi kehidupan keluarga. Kecemburuan telah menjadi beban yang berat tatkala relasi di antara suami dan istri mulai mengendur. Apalagi jika ada PIL (Pria Idaman Lain) dan WIL (Wanita Idaman Lain) mulai menggeser cinta di antara suami-istri. Padahal sesungguhnya kecemburuan itu terjadi bisa saja terjadi karena "komunikasi" yang kurang antara suami-istri. Kecemburuan bisa diatasi jika suami-istri selalu berkomunikasi secara baik dan terbuka, jika dalam pekerjaan ataupun relasi sosial ada teman/sahabat dan bukan PIL/WIL.

c) Miras (Minuman Keras)

Miras telah menjadi sebab terjadinya KDRT karena miras telah menjadi bagian dari kehidupan masyarakat tertentu sehingga dapat dinikmati setiap waktu. Miraslah menjadi pemicu adanya KDRT karena ketika suami/istri meneguk miras, istri/suami/ dan atau anak bisa menjadi korban kekerasan. Dengan miras peminumnya akan terimajinasi oleh hal-hal yang negatif, bisa memperkosa, memaki, dan bahkan membunuh. Itulah sebabnya miras memicu terjadinya KDRT.

Menurut pasal 9 UU No 23 tahun 2004 tentang Penghapusan Kekerasan dalam Rumah Tangga (PKDRT), diatur tentang kekerasan ekonomi atau penelantaran ekonomi. Penelantaran Ekonomi, yaitu Perbuatan seseorang yang menurut hukum atau karena persetujuan atau perjanjian ia wajib memberikan kehidupan, perawatan, atau pemeliharaan kepada orang tersebut yang mengakibatkan ketergantungan ekonomi dengan cara membatasi dan/atau melarang untuk bekerja yang layak di dalam atau di luar rumah sehingga korban berada di bawah kendali orang tersebut. Sebenarnya, kekerasan ekonomi tidak hanya terbatas pada penelantaran ekonomi semata. Kekerasan ekonomi bisa terbagi dalam kekerasan ekonomi berat dan ringan. Kekerasan ekonomi berat pada dasarnya adalah tindakan yang mengekploitasi secara ekonomi, 
memanipulasi dan mengendalikan korban lewat sarana ekonomi. Beberapa bentuk kekerasan ekonomi adalah:

a) memaksa korban bekerja;

b) melarang korban bekerja namun tidak memenuhi haknya dan menelantarkannya;

c) mengambil tanpa sepengetahuan dan tanpa persetujuan korban, merampas dan atau memanipulasi harta benda korban.

Kekerasan Ekonomi yang dikategorikan ringan, yaitu tindakan yang berupa upaya-upaya sengaja yang menjadikan korban tergantung atau tidak berdaya secara ekonomi. Dalam kehidupan masyarakat seringkali kita jumpai perempuan yang bekerja ketika menikah keluar dari pekerjaannya. Perempuan diharapkan lebih fokus mengurusi urusan rumah tangga, mempersiapkan kehamilan, kelahiran, memberikan ASI hingga 2 tahun, dan pengasuhan pertama bagi anakanak. Karena kondisi inilah, maka menjadi alasan penting mengapa laki-laki bertanggung jawab terhadap kehidupan dan keberlangsungan ekonomi keluarga. Banyak sekali perempuan yang meninggalkan pekerjaan publiknya dan menyerahkan dirinya untuk keluarga. Namun, ada banyak kasus suami yang seharusnya menjalankan tanggung jawabnya untuk memenuhi seluruh kebutuhan keluarga, ternyata tidak melakukan hal itu. Beberapa contoh kasus misalnya:

a) Ibu A menikah dengan seorang pejabat desa, tetapi untuk kebutuhan seharihari diberi uang yang sangat terbatas. Pernah mengatakan kurang dan meminta tambahan untuk bisa membeli kebutuhan sehari-hari namun malah dimarahi. Sejak saat itu ibu A tidak pernah meminta nafkah, hanya menerima bila diberi. Meski istri pejabat desa namun ibu A merasa tertekan karena benar-benar sangat tergantung secara ekonomi pada suami, sementara suami hanya memberikan uang dengan sangat terbatas bahkan sebenarnya tidak cukup untuk kebutuhan sehari-hari.

b) Ibu B diberi semua sisa penghasilan suami yang setiap beberapa bulan pulang dari bekerja di luar kota, setelah dikurangi dengan biaya hidup suami saat 
merantau. Namun, setiap akan kembali ke tempat dia merantau, suami selalu meminta uang kepada istri dengan jumlah yang tidak jauh besarnya dengan saat memberikan. Sementara ibu B harus menyediakan semua kebutuhan suami yang bila dinilai dengan uang jumlahnya juga tidak sedikit. Ibu B terpaksa kerja serabutan untuk menutup kebutuhan rumah tangga.

c) Kasus ibu $\mathrm{C}$ tidak jauh berbeda dengan ibu A. Ibu C menikah dengan suami yang mempunyai pekerjaan baik dengan gaji cukup. Ibu C selalu mendapat jatah uang bulanan dari suami. Namun seiring berjalannya waktu ternyata jatah uang bulanan berkurang bahkan akhirnya sering tidak diberikan. Suami malah mempunyai WIL (wanita idaman lain) dan tidak peduli terhadap anak dan istrinya. Terpaksa ibu C pontang panting memenuhi kebutuhan seharihari, bahkan anak-anaknya juga terpaksa putus sekolah dan membantu mencari nafkah. Harta benda juga banyak diambil suami dan dijual tanpa sepengetahuan ibu $\mathrm{C}$, termasuk barang-barang yang dibeli sendiri dari hasil kerja keras ibu C. Suamipun pergi meninggalkan keluarga, padahal ibu C masih harus menutup pinjaman bank yang digunakan oleh suami karena menggunakan namanya atau tidak terpenuhi kebutuhan dasarnya. 9

Persoalan seperti ini banyak sekali terjadi. Biasanya suami mempunyai uang namun hanya sebagian kecil yang diberikan pada istri untuk menutup semua kebutuhan keluarga. Sebagian masyarakat mengenal istilah 'duwit lanang, duwit wedhok (uang laki-laki, uang perempuan) artinya uang yang diperuntukkan bagi suami dan uang bagian istri. Biasanya, uang untuk suami adalah untuk pemenuhan kebutuhan sekunder dan tertier, sedangkan uang bagian istri untuk pemenuhan kebutuhan sehari-hari. Uang yang diberikan kepada istri dengan jumlah terbatas memaksa istri untuk mengantur dengan sangat cermat pengeluaran keluarga, dan seringkali mengorbankan kebutuhan-kebutuhan pribadi. Hal semacam ini

\footnotetext{
9 http://solider.or.id/2014/07/14/panduan-hukum-memahami-kekerasan-dan-penelantaranekonomi. Diakses tanggal 12 April 2016.
} 
biasanya tidak dianggap sebagai persoalan bila tidak dibarengi dengan persoalanpersoalan lain seperti perselingkuhan, kekerasan fisik atau berbagai bentuk kekerasan lainnya.

Kasus lainnya, adalah suami yang tega menjual istrinya demi meraup rupiah. Seperti kisah ibu D di mana martabatnya sebagai perempuan, istri, dan seorang ibu ditukar televisi dan beberapa barang lain oleh suaminya. Ibu D yang tinggal di sebuah desa pernah kaget bukan kepalang. Karena suami yang selama ini dipercaya ternyata tega membawa ibu D kepada mandor suaminya untuk disetubuhi. Awalnya ibu D tidak tahu bahwa perkosaan yang dilakukan mandor suaminya tersebut atas rencana suami dengan perjanjian akan mendapatkan sejumlah uang. Ibu D hanya tahu suami membeli beberapa perabot baru seperti televisi. Ternyata uang untuk membeli perabot tersebut dari si Mandor.

Anak-anak juga tidak luput menjadi korban kekerasan ekonomi dari orangorang yang seharusnya bertanggung jawab atas dirinya. Kasus penelantaran anak, pemaksaan anak-anak untuk bekerja, bahkan menjual anak dan menjual kegadisan anak untuk mendapatkan sejumlah uang tertentu pernah terjadi. Kekerasan ekonomi juga banyak terjadi pada difabel. ${ }^{10}$ Banyak kasus difabel yang digunakan sebagai alat mencari belas kasihan. Difabel juga rentan mengalami penelantaran ekonomi, tidak dirawat dengan baik sehingga asupan makannya terbatas, bahkan ada yang dibiarkan saja oleh keluarganya saat mengalami sakit. Adapun Kekerasan ekonomi dalam rumah tangga tercantum dalam UU PKDRT yang menyebutkan bahwa: ${ }^{11}$

'Dipidana dengan pidana penjara paling lama 3 tahun atau denda paling banyak Rp. 15.000.000,00 (lima belas juta rupiah), setiap orang yang:

1. Menelantarkan orang lain dalam lingkup rumah tangganya sebagaimana dimaksud dalam pasal 9 ayat (1);

2. Menelantarkan orang lain sebagaimana dimaksud pasal 9 ayat (2).'

\footnotetext{
10 Difabel (difable) atau yang sering disebut juga sebagai "kaum difabel" adalah orang yang memiliki keterbatasan fisik atau penyandang cacat fisik dan mental.

11 Pasal 49, Undang-Undang Nomor 23 Tahun 2004 tentang Penghapusan Kekerasan dalam Rumah Tangga.
} 
Menurut Undang-Undang Nomor 23 Tahun 2004, tindak kekerasan terhadap isteri dalam rumah tangga dibedakan kedalam 4 (empat) macam, yaitu:

\section{1.) Kekerasan Fisik}

Kekerasan fisik adalah perbuatan yang mengakibatkan rasa sakit, jatuh sakit atau luka berat. Perilaku kekerasan yang termasuk dalam golongan ini antara lain adalah menampar, memukul, meludahi, menarik rambut (menjambak), menendang, menyulut dengan rokok, memukul/melukai dengan senjata dan sebagainya. Biasanya perlakuan ini akan nampak seperti bilurbilur, muka lebam, gigi patah atau bekas lainnya. Kekerasan fisik sangat bervariasi atau bermacam-macam bentuknya, baik yang dialami oleh isteri dan atau anak sebagai korban. Kekerasan fisik yang dimaksudkan disini tidak semata-mata berkaitan dengan fisik dalam pengertian tubuh korban, seperti melakukan kekerasan fisik (penganiayaan) seperti: ditampar, dipukul menggunakan alat, ditinju, ditendang, membanting ke lantai, membenturkan kepala ke tembok rumah dan ada juga yang menginjak perut korban serta ada juga yang mengancam dengan menggunakan parang tetapi juga yang berhubungan dengan material/property yang dimiliki keluarga. Hal mana dapat disebutkan bahwa pelaku melakukan tindakan menghancurkan, memecahkan atau merusak barang-barang yang ada.

\section{2.) Kekerasan Psikologis}

Kekerasan psikologis atau emosional adalah perbuatan yang mengakibatkan ketakutan, hilangnya rasa percaya diri, hilangnya kemampuan untuk bertindak, rasa tidak berdaya dan/atau penderitaan psikis berat pada seseorang. Perilaku kekerasan yang termasuk penganiayaan secara emosional adalah penghinaan, komentar-komentar yang menyakitkan atau merendahkan harga diri, mengisolir isteri dari dunia luar, mengancam atau menakut-nakuti sebagai sarana memaksakan kehendak. Kekerasan psikologis ini lebih berdampak pada kejiwaan dan umumnya pemulihannya tidaklah mudah, bahkan dapat melampaui waktu yang cukup lama. 


\section{3.) Kekerasan Seksual}

Kekerasan jenis ini meliputi pengisolasian (menjauhkan) isteri dari kebutuhan batinnya, memaksa melakukan hubungan seksual, memaksa selera seksual sendiri, tidak memperhatikan kepuasan pihak isteri.

\section{4.) Kekerasan Ekonomi}

Setiap orang dilarang menelantarkan orang dalam lingkup rumah tangganya, padahal menurut hukum yang berlaku baginya atau karena persetujuan atau perjanjian ia wajib memberikan kehidupan, perawatan atau pemeliharaan kepada orang tersebut. Contoh dari kekerasan jenis ini adalah tidak memberi nafkah isteri, bahkan menghabiskan uang isteri.

\section{Upaya Hukum Penanganan Kasus Kekerasan Dalam Rumah Tangga berdasarkan Kitab Undang-undang Hukum Pidana (KUHP) dan Pasca berlakunya Undang-Undang Nomor 23 Tahun 2004}

Sebelum ada Undang-Undang KDRT jika terjadi tindak kekerasan dalam lingkup keluarga atau rumah tangga selalu ditangani berdasarkan Kitab UndangUndang Hukum Pidana (KUHP). Petugas yang menangani adalah Polisi baik lakilaki maupun perempuan (Polwan). Penanganan kasus yang menimpa perempuan seringkali tidak memuaskan bahkan cenderung menambah penderitaan korban. Hal ini disebabkan karena korban sering menjadi korban ganda, artinya, korban harus selalu mengulang-ulang menceritakan perbuatan yang tidak mengenakkan yang pernah menimpa dirinya. Ruang Pelayanan Khusus yang terdapat di Polres/Polresta sangat membantu menangani kasus-kasus khusus yang menimpa perempuan dan anak, misalnya tindak pidana kesusilaan, kekerasan dalam rumah tangga dan tindak pidana yang dilakukan oleh anak. Akan tetapi, tindak pidana umum tetap ditangani oleh aparat kepolisian yang lain. Masing-masing kasus baik yang khusus menimpa perempuan dan anak maupun masyarakat umum, tetap ditangani berdasar Kitab Undang-Undang Hukum Pidana. Saat ini sebagian dari korban semakin terbuka dan berani melaporkan tindak kekerasan yang dahulu selalu ditutup-tutupi. 
Adapun bagi pelaku dan masyarakat diharapkan lebih tanggap dan mengerti bahwa tindak kekerasan terhadap istri atau anak dan pembantu adalah suatu perbuatan yang dapat dihukum. Rumah tangga merupakan bentuk masyarakat yang paling kecil yang biasanya terdiri atas ayah, ibu, dan anak. Sebuah rumah tangga diharapkan memancarkan kebahagiaan dan kehangatan penuh cinta kasih. Namun seringkali terjadi kegoncangan dalam rumah tangga tersebut berupa tindakan kekerasan yang dilakukan oleh suami pada istri. Perbuatan tersebut oleh masyarakat dan bahkan oleh korban (istri) dianggap merupakan masalah internal atau masalah pribadi antara suami istri.

Kenyataannya kekerasan dalam rumah tangga mengandung norma-norma hukum pidana, tetapi terdapat beberapa perkembangan dari delik yang sudah ada. $^{12}$ Perkembangan tersebut sebagai akibat atau dampak adanya suatu kebutuhan. Karena kalau kita kaji sebetulnya tindak kekerasan yang terdapat dalam rumah tangga sudah diatur dalam Kitab Undang-undang Hukum Pidana (KUHP). Namun, karena yang diatur dalam Kitab Undang-undang Hukum Pidana terlalu umum dan luas, maka perlu kiranya ada undang-undang yang lebih spesifik untuk mengaturnya.

Kekerasan dalam rumah tangga telah memenuhi unsur-unsur tindak pidana atau perbuatan pidana, mengingat bentuk-bentuk kekerasan dalam rumah tangga, juga terdapat dalam Kitab Undang-Undang Hukum Pidana (KUHP). Namun dengan adanya perkembangan dalam hukum pidana dan munculnya delik-delik baru, maka dibentuklah peraturan yang lebih spesifik walaupun secara umum dalam kitab undang-undang, pengaturan tentang hal tersebut sudah ada. Dalam Hukum Pidana (KUHP) telah diatur mengenai penganiayaan dan kesusilaan serta penelantaran orang yang perlu diberi nafkah. Undang-Undang nomor 23 Tahun 2004 mempunyai hubungan yang erat dengan Kitab undang-undang Hukum Pidana (KUHP). Pasal yang berkaitan antara Kitab Undang-Undang Hukum Pidana (KUHP) dengan Undang-Undang Nomor 23 Tahun 2004 adalah Pasal 10 KUHP

12 Andi, Hamzah., Delik-Delik tertentu (Special delicten) di dalam KUHP, Sinar Grafika, Jakarta, 2011, hlm. 18. 
tentang jenis-jenis pidana. Pasal 10 KUHP ini masih relevan diterapkan pada kasus kekerasan dalam rumah tangga. Pidana yang dijatuhkan pada pelaku Kekerasan dalam Rumah Tangga adalah pidana penjara atau denda. Kecuali pidana tambahan yang berbeda. Ada beberapa pasal dalam Kitab Undang-Undang Hukum Pidana (KUHP) yang mengandung pengertian kekerasan, yakni:

\section{Pasal 170 KUHP}

Penyerangan dengan tenaga bersama menggunakan kekerasan terhadap orang atau barang, diancam pidana penjara paling lama 5 (lima) tahun 6 (enam) bulan. Jika menghancurkan barang atau jika mengakibatkan luka-luka, pidana penjara paling Iama 7 (tujuh) tahun. Jika luka berat, pidana penjara paling lama 9 (sembilan) tahun. Jika mengakibatkan maut, pidana paling lama 12 (dua betas) tahun;

\section{Pasal 211 KUHP}

Kekerasan memaksa seorang pegawai negeri untuk melakukan perbuatan atau tidak melakukan perbuatan jabatan yang sah, pidana penjara paling lama 4 (empat) tahun;

\section{Pasal 212 KUHP}

Dengan kekerasan melawan seorang pegawai negeri yang sedang melaksanakan kewajibannya yang sah, dipidana penjara 1 (satu) tahun 4 (empat) bulan atau denda paling banyak Rp. 4.500, 00;

\section{Pasal 285 KUHP}

Dengan kekerasan memaksa seorang perempuan bersetubuh dengan dia di luar perkawinan, dipidana penjara paling lama 12 (dua belas) tahun.

\section{Pasal 289 KUHP}

Kekerasan memaksa seorang anak melakukan perbuatan cabul, pidana penjara paling lama 9 (sembilan) tahun;

\section{Pasal 300 KUHP}

Memaksa seseorang dengan kekerasan untuk minum-minuman yang memabukkan, dipidana penjara paling lama 1 (satu) tahun atau denda paling banyak Rp. 4.000,00;

\section{Pasal 330 KUHP}

Kekerasan menarik anak yang belum cukup umur dari orang tua dijatuhkan pidana penjara paling lama 9 (sembilan) tahun. 


\section{Pasal 332 KUHP}

Melarikan perempuan dengan menggunakan kekerasan, diancam penjara paling lama 9 (sembilan) tahun;

\section{Pasal 333 KUHP}

Perampasan kemerdekaan orang lain dengan kekerasan dipidana dengan pidana penjara paling lama 9 (sembilan) tahun;

\section{Pasal 335 KUHP}

Kekerasan memperlakukan orang lain dengan tidak menyenangkan diancam dengan pidana penjara paling lama 1 (satu) tahun atau denda paling banyak Rp. 4.500,00;

\section{Pasal 336 KUHP}

Mengancam dengan kekerasan terhadap twang atau barang secara terang-terangan dengan tenaga bersama, dipidana dengan pidana penjara paling lama 2 (dua) tahun 8 (delapan) bulan;

\section{Pasal 351 KUHP}

Penganiayaan diancam pidana penjara paling lama 2 (dua) tahun 8 (delapan) bulan atau denda paling banyak Rp. 300, 00. jika korban luka begat, yang bersalah dipidana penjara paling lama 5 (lima) tahun, jika korban mati, dikenakan pidana penjara paling lama 7 (tujuh) tahun.

\section{Pasal 353 KUHP}

Penganiayaan dengan rencana, diancam pidana penjara paling lama 4 (empat) tahun. Jika korban luka berat, dipidana penjara paling lama 7 (tujuh) tahun. Jika korban mati, dipidana penjara paling lama 9 (sembilan) tahun;

\section{Pasal 354 KUHP}

Penganiayaan berat, diancam pidana penjara paling lama 8 (delapan) tahun. Jika mengakibatkan kematian, pidana penjara paling lama 10 (sepuluh) tahun;

\section{Pasal 355 KUHP}

Penganiayaan berat dengan rencana, dipidana penjara paling lama 12 (dua belas) tahun. Jika mengakibatkan kematian, pidana penjara paling lama 15 (lima belas) tahun.

Dari beberapa contoh pasal dalam Kitab Undang-Undang Hukum Pidana yang mengatur tentang kekerasan dapat dilihat bahwa kekerasan yang dimaksud 
dalam pasal-pasal tersebut bersifat umum, tidak hanya terfokus dalam lingkup rumah tangga tetapi bisa di tempat umum, ${ }^{13}$ dan juga bisa menimpa siapa saja baik yang mempunyai hubungan darah atau tidak mempunyai hubungan darah bahkan tidak saling mengenal, maka untuk mengatasi kasus kekerasan dalam rumah tangga perlu adanya suatu produk hukum yang khusus mengatur kekerasan yang terjadi dalam lingkup rumah tangga.

Disahkannya Undang-Undang Nomor 23 Tahun 2004 tentang Penghapusan Kekerasan Dalam Rumah Tangga merupakan momen sejarah bagi bangsa Indonesia, khususnya bagi kaum perempuan dan kelompok masyarakat lainnya yang memiliki kepedulian terhadap masalah kekerasan dalam rumah tangga. Lahirnya undang-undang ini merupakan bagian dari penegakan Hak Asasi Manusia (HAM). Gagasan mengenai pentingnya sebuah Undang-Undang Kekerasan Dalam Rumah tangga didasarkan atas pengalaman para perempuan korban kekerasan dalam rumah tangga. Para korban tidak saja menggali tentang kekerasan fisik, tetapi juga kekerasan psikis, seksual, maupun ekonomi.

Lahirnya Undang-Undang ini dilandasi berbagai pertimbangan antara lain bahwa setiap warga negara berhak mendapatkan rasa aman dan bebas dari segala bentuk kekerasan. Dengan demikian segala bentuk kekerasan terutama kekerasan dalam rumah tangga merupakan pelanggaran hak asasi manusia. Tindak kekerasan terhadap perempuan ibarat gunung es. Karena yang muncul ke permukaan hanya sebagian kecil, sedangkan bagian yang lebih besar masih tenggelam atau tidak dapat diketahui. Kondisi ini dipengaruhi oleh adanya anggapan dalam masyarakat bahwa kekerasan terhadap perempuan dalam lingkungan keluarga adalah masalah internal keluarga dan tidak sepatutnya dipublikasikan. Sebagian masyarakat masih menutupi kondisi ini karena mereka mempertahankan status sosial bagi keluarganya. Sama halnya dengan bentuk kejahatan biasa pelaku tindak kekerasan dalam lingkungan keluarga atau dalam rumah tangga (KDRT) adalah mereka yang berasal dari berbagai status sosial.

13 Arief Barda Nawawi, Beberapa Aspek Kebijakan Penegakan dan Pengembangan Hukum Pidana, Citra Aditya Bakti, Bandung, 1998, hlm. 3. 
Salah satu terobosan hukum yang dilakukan melalui Undang-Undang Nomor 23 tahun 2004 tentang Penghapusan kekerasan dalam rumah Tangga adalah mengenai peran-peran Aparat Penegak Hukum khususnya kepolisian, advokat, dan pengadilan dalam memberikan perlindungan dan pelayanan bagi korban kekerasan dalam rumah tangga terutama sekali dengan diaturnya mengenai mekanisme perlindungan dari pengadilan demi keamanan korban.

Berikut ini adalah peran mereka dalam melindungi dan melayani korban, yang diatur dalam Undang-undang nomor 23 tahun 2004 tentang Penghapusan Kekerasan dalam rumah Tangga:

\section{Peran Kepolisian (Pasal 16-20)}

Saat kepolisian menerima laporan mengenai kasus kekerasan dalam rumah tangga, mereka harus segera menerangkan mengenai hak-hak korban untuk mendapatkan pelayanan dan pendampingan. Selain itu, sangat penting pula bagi pihak kepolisian untuk memperkenalkan identitas mereka serta menegaskan bahwa kekerasan dalam rumah tangga adalah sebuah kejahatan terhadap kemanusiaan sehingga sudah menjadi kewajiban dari kepolisian untuk melindungi korban. Setelah menerima laporan tersebut, langkahlangkah yang harus diambil kepolisian adalah:

a. Memberikan perlindungan sementara pada korban,

b. Meminta surat penetapan perintah perlindungan dari pengadilan, dan melakukan penyidikan.

\section{Peran Advokat (Pasal 25)}

Dalam hal memberikan perlindungan dan pelayanan bagi korban maka advokat wajib:

a) Memberikan konsultasi hukum yang mencakup informasi mengenai hakhak korban dan proses peradilan,

b) Mendampingi korban di tingkat penyidikan, penuntutan, dan pemeriksaan dalam sidang pengadilan dan membantu korban untuk secara lengkap memaparkan kekerasan dalam rumah tangga yang dialaminya, dan 
c) Melakukan koordinasi dengan sesama penegak hukum, relawan pendamping, dan pekerja sosial agar proses peradilan berjalan sebagaimana mestinya.

\section{Peran Pengadilan}

Sementara itu, undang-undang juga mengatur tentang peran pengadilan dalam memberikan perlindungan terhadap korban, khususnya mengenai pelaksanaan mekanisme perintah perlindungan. Kepolisian harusmeminta surat penetapan perintah perlindungan dari pengadilan. Setelah menerima permohonan itu, pengadilan harus:

a) Mengeluarkan surat penetapan yang berisi perintah perlindungan bagi korban dan anggota keluarga lain.

b) Atas permohonan korban atau kuasanya, pengadilan dapat mempertimbangkan untuk menetapkan suatu kondisi khusus yakni pembatasan gerak pelaku, larangan memasuki tempat tinggal bersama, larangan membuntuti, mengawasi atau mengintimidasi korban. Apabila terjadi pelanggaran perintah perlindungan maka korban dapat melaporkan hal ini kepada kepolisian, kemudian secara bersama-sama menyusun laporan yang ditujukan kepada pengadilan. Setelah itu, pengadilan wajib memanggil pelaku untuk mengadakan penyelidikan dan meminta pelaku untuk membuat pernyataan tertulis yang isinya berupa kesanggupan untuk mematuhi perintah perlindungan. Apabila pelaku tetap melanggar surat pernyataan itu, maka pengadilan dapat menahan pelaku sampai 30 hari lamanya. Dalam memberikan perlindungan terhadap korban ini, aparat penegak hukum dapat bekerja sama dengan tenaga kesehatan, pekerja sosial, relawan pendamping, dan pembimbing rohani untuk mendampingi korban. 


\section{Peran Tenaga Kesehatan}

Setelah mengetahui adanya kasus kekerasan dalam rumah tangga maka petugas kesehatan berkewajiban untuk memeriksa kesehatankorban, kemudian membuat laporan tertulis mengenai hasil pemeriksaan serta membuat visum et repertum atau surat keterangan medis lain yang memiliki kekuatan hukum untuk dijadikan alat bukti.

\section{Peran Pekerja Sosial}

Dalam melayani korban kasus kekerasan dalam rumah tangga, ada beberapa hal yang harus dilakukan oleh pekerja sosial:

a. Melakukan konseling untuk menguatkan korban,

b. Menginformasikan mengenai hak-hak korban,

c. Mengantarkan korban ke rumah aman, dan

d. Berkoordinasi dengan pihak kepolisian, dinas sosial dan lembaga lain demi kepentingan korban.

\section{Peran Pembimbing Rohani}

Demi kepentingan korban, maka pembimbing rohani harus memberikan penjelasan mengenai hak, kewajiban, dan memberikan penguatan iman serta takwa kepada Tuhan Yang Maha Esa.

\section{Peran Relawan Pendamping}

Sementara itu, salah satu terobosan hukum lain dari Undang-undang Penghapusan Kekerasan Dalam rumah Tangga adalah tugas dari relawan pendamping, yakni:

a) Menginformasikan mengenai hak korban untuk mendapatkan seorang atau lebih pendamping,

b) Mendampingi korban di tingkat penyidikan, penuntutan atau tingkat pemeriksaan pengadilan dengan membimbing korban agar dapat memaparkan kekerasan yang dialaminya secara objektif dan lengkap;

c) Mendengarkan segala penuturan korban, dan

d) Memberikan penguatan kepada korban secara psikologis maupun fisik. 
Sebagian masyarakat masih menganggap kekerasan dalam rumah tangga bukan perbuatan pidana, tetapi merupakan aib yang harus ditutupi. Dengan demikian, baik korban sendiri maupun keluarga cenderung membiarkan tindak kekerasan tersebut terjadi. Beberapa orang istri yang sudah tidak tahan dengan keadaan tersebut memilih untuk bercerai, tetapi masih banyak istri yang tetap bertahan meskipun selalu mengalami kekerasan. ${ }^{14}$ Jadi, ini merupakan kejahatan yang tersembunyi. Ada beberapa hal yang menjadi alasan istri tetap bertahan meskipun setiap kali mengalami tindakan kekerasan, yaitu:

1. Perceraian dilarang oleh agama dan merupakan perbuatan yang tidak baik;

2. Khawatir anak;

3. Anaknya terlantar;

4. Ada ketergantungan ekonomi terutama bagi istri yang tidak bekerja;

5. Tidak ingin bercerai karena mempertahankan status di masyarakat; dan

6. Masih terdapat anggapan masyarakat bahwa status janda cerai sebagai individu yang bermasalah.

Adanya Undang-Undang Nomor 23 Tahun 2004 tentang Penghapusan Kekerasan Dalam Rumah Tangga menjadikan payung hukum bagi para korban kekerasan dalam rumah tangga. Pandangan mereka sudah mulai berubah sehingga kasus-kasus kekerasan dalam rumah tangga sudah mulai banyak yang dilaporkan ke pihak yang berwenang. Dengan demikian, sebagian masyarakat sudah mulai memberikan laporan-laporan tentang tindak kekerasan yang dialami atau yang dilihat. Hal ini didukung oleh karena adanya sosialisasi dari undangundang tersebut yang membuat korban mengerti bahwa kekerasan dalam rumah tangga merupakan tindak pidana sehingga para korban sudah lebih berani melapor. Pada satu tindak pidana atau perbuatan pidana terdapat 2 (dua) komponen pokok yaitu pelaku dan korban tindak pidana. Pada kasus kekerasan dalam rumah tangga faktor pemicu terjadinya kekerasan tidak dapat diperinci satu persatu, karena timbulnya tindakan kekerasan tersebut dipengaruhi dan

14 Wirjono Prodjodikoro, Tindak-Tindak Pidana Tertentu di Indonesia, Eresco, Jakarta, 1974, hlm. 57. 
tergantung pada faktor tertentu antara pelaku dan korban. Pihak korban dapat berperan secara langsung atau tidak langsung tergantung dari situasi dan kondisi Faktor pencentus terjadinya tindak kekerasan dalam rumah tangga tidak sama antara satu kasus dengan kasus yang lain. Penanganan terhadap kasus tersebut tergantung pada korban. Karena ada korban yang tidak mau melapor dan membiarkan dirinya sendiri menjadi korban karena alasan tertentu.

Namun ada juga korban yang mempunyai tekad yang kuat untuk menyelesaikan masalah rumah tangga tersebut melalui jalur hukum. Oleh karena itu, meskipun kekerasan dalam rumah tangga merupakan masalah sosial di mana setiap orang yang mengetahui terjadinya kekerasan bisa melapor sepenuhnya masih tergantung pada kehendak korban, karena dalam kenyataannya masih banyak korban kekerasan dalam rumah tangga yang mencabut laporannya kepada polisi. Tindakan kekerasan yang terjadi dalam rumah tangga mempunyai sifat istimewa dan khusus. Keistimewaan perbuatan ini terletak pada hubungan antara pelaku dan korban. Pada kasus-kasus tindak pidana yang lain kadang-kadang pelaku tidak mengenal korban sama sekali dan seringkali tidak mempunyai hubungan. Tetapi, pada kekerasan dalam rumah tangga pelaku dan korban mempunyai hubungan khusus yaitu hubungan perkawinan (suami istri), hubungan darah (orang tua, anak, kemenakan) atau hubungan adanya ikatan kerja misalnya pembantu rumah tangga dan tinggal dalam satu rumah dengan pelaku. ${ }^{15}$

Perlindungan korban dalam proses peradilan pidana tidak terlepas dari perlindungan korban menurut ketentuan hukum positif yang berlaku. Perlindungan bagi korban tindak kekerasan yang terjadi dalam rumah tangga diatur dalam Undang-Undang Nomor 23 Tahun 2004 tentang Penghapusan Kekerasan Dalam Rumah Tangga. Diharapkan undang-undang ini dapatmelindungi para korban, karena dalam undang-undang diatur tentang sanksi bagi pelaku kekerasan dalam rumah tangga. Sanksi tersebut berupa pidana penjara atau pidana denda. Di samping itu, masih ditambah adanya pidana

\footnotetext{
15 Shanty, Dellyana, Wanita dan Anak-Anak di mata Hukum, Liberty, Yogyakarta, 1988, hlm., 20.
} 
ambahan bagi pelaku. Selain itu dalam undang-undang tersebut juga mengatur tentang hak-hak para korban. Misalnya perlindungan agar bebas dari ancaman pelaku, mendapat perawatan medis, penempatan di rumah aman, atau korban dapat mengajukan gugatan ganti rugi. Ketentuan pidana dalam Undang-Undang Nomor 23 Tahun 2004 diatur dalam Bab VIII, yakni:

\section{Pasal 44 untuk kekerasan fisik:}

Pidana penjara paling lama 5 (lima) tahun atau denda paling banyak Rp. 15.000.000, 00. jika korban sakit atau luka berat, pidana penjara paling lama 10 (sepuluh) tahun atau denda paling banyak Rp. 30.000.000, 00. Jika korban mati, pidana penjara paling lama 15 (lima betas) tahun, atau denda paling banyak Rp.45.000.000, 00.

\section{Pasal 45 untuk kekerasan psikis,}

Dipidana penjara paling lama 3 (tiga) tahun atau denda paling banyak Rp 9.000.000, 00.

\section{Pasal 46 untuk kekerasan seksual,}

Pidana penjara paling lama 12 (dua betas) tahun atau denda paling banyak Rp. 36.000.000, 00.

\section{Pasal 49 untuk penelantaran rumah tangga,}

Pidana penjara paling lama 3 (tiga) tahun atau denda paling banyak Rp 15.000.000.

Dengan adanya produk hukum baru ini maka usaha penanganan kasus-kasus kekerasan dalam rumah tangga bisa terakomodir lebih baik jika dibandingkan dengan Kitab Undang-undang Hukum Pidana (KUHP). Selain itu dengan adanya sosialisasi dari undang-undang ini, maka laporan kasus kekerasan dalam rumah tangga semakin meningkat dan itu berarti bahwa masyarakat mulai memahami bahwa kekerasan dalam rumah tangga bukan hanya masalah yang sepele saja atau hanya masalah keluarga biasa yang harus ditutupi tetapi merupakan pelanggaran Hak Asasi Manusia (HAM). ${ }^{16}$

\footnotetext{
${ }^{16}$ Bagir Manan, Perkembangan Pemikiran dan Pengaturan Hak Asasi Manusia di Indonesia, Alumni, Bandung, 2000, hlm. 207.
} 
Telah diuraikan bahwa tindak kekerasan dapat berakibat fatal bagi korban, sehingga penanganan yang tepat merupakan solusi yang harus dilakukan pada korban agar reaksi fatal tersebut tidak berlarut-larut dan dapat menimbulkan gangguan fungsional yang lebih parah, baik dari segi fisik, mental personal, maupun sosial. Selama ini penanganan dititik beratkan pada korban. Penanganan korban melibatkan pula penanganan pada keluarga korban, karena pada umumnya mereka menjadi apa yang disebut sebagai second victims. Penanganan ini tidak dapat hanya dilakukan oleh satu dua pihak, namun sebaiknya terkait dalam hubungan kerjasama antar beberapa pihak. 17

Bentuk penanganan bagi korban pada umumnya adalah pemeriksaan visum oleh Rumah Sakit yang ditunjuk untuk itu atas permintaan Kepolisian, untuk kemudian korban mendapat dampingan dan advokasi serta ditangani secara personal melalui konsultasi medis dan psikologis. ${ }^{18}$ Penanganan hukum merupakan tindakan yang juga dilakukan untuk melindungi perempuan korban kekerasan akan hak pemulihannya.

\section{Penutup}

Dari uraian yang dikemukakan sebelumnya maka dapat ditarik kesimpulan yaitu: berkembangnya Kriminologi dan semakin maraknya pemikiran-pemikiran kritis yang mengarah pada studi untuk mempelajari proses-proses pembuatan undang-undang, maka penting bagi mahasiswa fakultas hukum untuk mempelajari kriminologi, agar dapat diperoleh pemahaman yang baik tentang fenomena kejahatan dan juga masalah hukum pada umumnya. Kekerasan yang diatur dalam Kitab Undang-Undang Hukum Pidana masih sangat umum, dimana terjadi bukan hanya di lingkup rumah tangga dan bisa menimpa siapa saja. Sehingga upaya hukum pada kasus kekerasan dalam rumah tangga berdasarkan KUHP belum maksimal, karena banyak kasus KDRT yang masih tersembunyi dan tidak dilaporkan kepada pihak kepolisian.

\footnotetext{
17 M. Munandar Sulaeman \& Siti Homzah, Kekerasan terhadap Perempuan, Tinjauan dalam berbagai Disiplin Ilmu \& Kasus Kekerasan, Refika Aditama. Bandung, 2010, hlm. 71. 18 Id.
} 
Dengan berlakunya Undang-Undang Nomor 23 Tahun 2004 tentang Penghapusan kekerasan dalam rumah tangga, maka masyarakat mulai memahami bahwa kekerasan dalam rumah tangga merupakan suatu tindak pidana yang harus dilaporkan ke kepolisian dan bukan hanya masalah keluarga saja. Upaya untuk penanganan kasus kekerasan dalam rumah tangga yang diatur pasca berlakunya Undang-Undang ini sudah efektif. Dengan adanya peran aparat penegak hukum baik kepolisian, advokat, dan pengadilan serta bekerja sama dengan tenaga kesehatan, pekerja sosial, pembimbing rohani, dan relawan pendamping. Oleh karena itu, perlu adanya peran aktif dari masyarakat untuk melapor ke kepolisian jika terjadi kekerasan dalam rumah tangga.

\section{Daftar Pustaka}

\section{Buku}

Atmasasmita Romli. H, Teori dan Kapita Selekta Krimonologi, Refika Aditama, Bandung, 2007.

Davies Miranda,(Ed.) women and violence: Realities and Responses World Wide, 2nd ed, London and new York ; zed books Ltd.,1997.

Dellyana Shanty, Wanita dan Anak-Anak di mata Hukum, (Liberty, Yogyakarta,1988).

Hamzah Andi, Delik-Delik Tertentu (Special delicten), Sinar Grafika,Jakarta, 2011.

Manan Bagir, Perkembangan Pemikiran dan Pengaturan Hak Asasi Manusia di di Indonesia, Alumni, Bandung, 2000.

Nawawi Barda Arief, Beberapa Aspek Kebijakan Penegakan dan Pengembangan Hukum Pidana, Citra Aditya Bakti, Bandung, 1998.

Prodjodikoro Wirjono, Tindak-Tindak Pidana Tertentu di Indonesia, Eresco, Jakarta, 1974.

Soekanto Soerjono, Faktor-faktor yang Mempengaruhi Penegakan Hukum, Raja Grafindo Perkasa, Jakarta, Cet.ke-13, 2014.

Sulaeman Munandar M \& Homzah Siti, Kekerasan terhadap Perempuan, Tinjauan dalam berbagai Disiplin Ilmu \& Kasus Kekerasan, Refika Aditama. Bandung, 2010.

Sunggono Bambang, Metodologi Penelitian Hukum, Raja Grafindo Persada, Jakarta, 2002. 


\section{Jurnal \& Website}

Blog Jurnal Hukum, perlindungan terhadap perempuan melalui undang-undang kekerasan dalam rumah tangga: analisa perbandingan antara Indonesia dan India, diakses tanggal 28 Januari 2016.

Jurnal Hukum, perlindungan terhadap perempuan melalui undang-undang kekerasan dalam rumah tangga: analisa perbandingan antara Indonesia dan India, diakses tanggal 28 Januari 2016.

http://pipi-megawati.blogspot.com/2011/10/kriminologi.html, Diakses tanggal 15 Januari 2016.

http://solider.or.id/2014/07/14/panduan-hukum-memahami-kekerasan-danpenelantaran-ekonomi. Diakses tanggal 12 April 2016.

www.pemantauperadilan.com, Kekerasan Dalam Rumah Tangga, Diakses tanggal 29 Januari 2016.

\section{Undang-Undang}

Undang-Undang No. 1 Tahun 1974 Tentang Perkawinan

Undang-Undang No. 23 Tahun 2004 tentang Penghapusan Kekerasan Dalam Rumah Tangga 